\title{
Synthesis of Estrone Methyl Ether
}

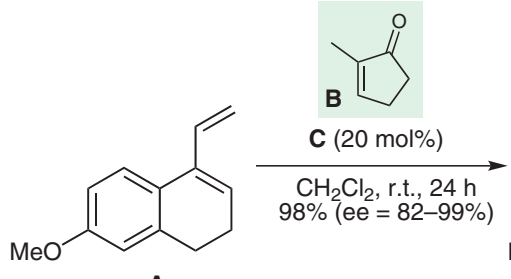

A<smiles>COc1ccc2c(c1)CCC1C2CCC2(C)C(=O)CCC12</smiles>

D<smiles>COc1ccc2c(c1)CCC1=C2CCC2(C)C(=O)C=CC12</smiles>

E

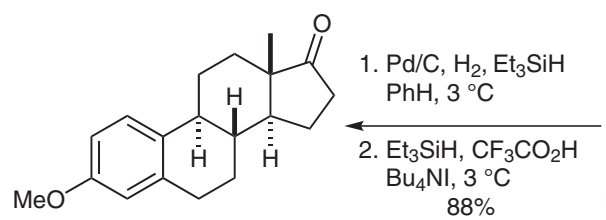

Estrone methyl ether<smiles>COc1ccc2c(c1)CCC1=C2CCC2(C)C(=O)CC=C12</smiles>

F

Preparation of catalyst $\mathbf{C}$ :

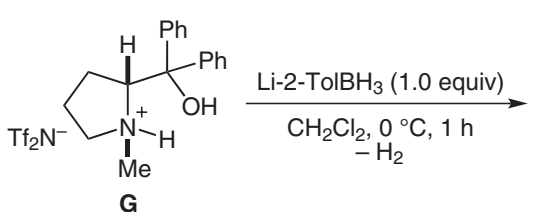

G<smiles>[Y15][N+]12CCCC1(c1ccccc1)C(C)OB2c1ccccc1C</smiles>

$\mathrm{H}$

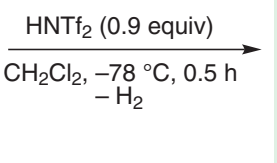

LHMDS ( 2.0 equiv) $\mathrm{THF},-78^{\circ} \mathrm{C}$

then $\mathrm{AcOH}$ (20 equiv)
Synthesis of Natura

Products and

Potential Drugs

\section{Key words}

estrone

asymmetric DielsAlder reaction

oxazaborolidine
Significance: Canales and Corey report a remarkably short and efficient synthesis of estrone methyl ether which exploits a novel $\mathrm{N}$-methyloxazaborolidinium cation as a Lewis acid catalyst for an asymmetric Diels-Alder reaction. The paper cites ten further examples all proceeding with excellent yields and ee values. The reactions typically proceed in dichloromethane at $-78^{\circ} \mathrm{C}$ but in the estrone synthesis depicted, the cycloaddition was performed at room temperature. The ee of the adduct $\mathbf{D}(82 \%)$ was raised to $99 \%$ by one recrystallization.
Comment: The highly reactive catalyst $\mathbf{C}$ was generated in situ prior to use. It could not be generated by $\mathrm{N}$-methylation of the corresponding oxazaborolidine; nor could it be generated by the reaction of $\mathrm{N}$-methyl-1,1-diphenyl-pyrrolidinomethanol or the corresponding bistrimethylsilyl ether with $\mathrm{ArBBr}_{2}$ or $\mathrm{ArB}(\mathrm{OTf})_{2}$. For a related synthesis of estrone methyl ether see: Y.-Y. Yeung, R.-J. Chein, J. E. Corey J. Am. Chem. Soc. 2007, $129,10346$. 